\title{
МЕЖВУЗОВСКИЙ МЕЖДИСЦИПЛИНАРНЫЙ СЕМИНАР КАК ФОРМА НАУЧНОЙ КОММУНИКАЦИИ
}

\section{INTER-UNIVERSAL INTERDISCIPLINARY SEMINAR AS A FORM OF SCIENTIFIC COMMUNICATION}

\section{O. Litovchenko}

Summary: The purpose of this study is to analyze the activities of a scientific seminar at the university, determine its role and main functions, the importance of the seminar in building scientific communication, as well as its importance in working with young scientists. The main functions of the scientific seminar, its forms, methods of organization, the role in the organization of scientific work of young scientists are considered, the experience of the interuniversity interdisciplinary scientific seminar «Actual problems of human adaptation» is described. Scientific is an effective form of scientific communication both at the level of the university and the region.

Keywords: scientific seminar; scientific communication; forms of a scientific seminar, functions of a scientific seminar, human adaptation, young scientists.
Литовченко Ольга Геннадьевна Д.б.н., доцент, БУ ВО «Сургутский государственный университет» olgalitovchenko@mail.ru

Аннотация: Целью данного исследования: анализ деятельности научного семинара в университете, определение его роли и основных функций, значение семинара в выстраивании научной коммуникации, а также значения в работе с молодыми учеными. Рассматриваются основные функции научного семинара, его формы, способы организации, роль в организации научной работы молодых ученых, описан опыт работы межвузовского междисциплинарного научного семинара «Актуальные вопросы адаптации человека». Научный является эффективной формой научной коммуникации как на уровне вуза, так и региона.

Ключевые слова: научный семинар; научная коммуникация; формы научного семинара, функции научного семинара, адаптация человека, молодые ученые.

следовательский задел по данному направлению, сложились коллективы ученых.

Проблема изучения адаптации человека к различным условиям жизнедеятельности является междисциплинарной и в настоящее время приобретает особую актуальность. Рассмотрение вопросов адаптации человека на межвузовском междисциплинарном семинаре позволяет найти новые грани данной научной темы. Научный семинар привлек к обсуждению разнообразных вопросов адаптации студентов, магистрантов, аспирантов, научных сотрудников, ведущих исследователей вузов и научных организаций, что дает участникам возможность получить полезный опыт и компетенции. Осуществление межвузовского взаимодействия приводит к консолидации имеющихся материальных и интеллектуальных ресурсов, направить их на решение актуальных научных задач, связанных со сбережением здоровья организма человека, рассмотреть адаптационные стратегии в профессиональной, спортивной и учебной деятельности, при физической и психической нагрузке, в различных социальных, экологических, климатических условиях, в том числе и при действии суровых климатогеографических факторов северного региона нашей страны [2].

Научный семинар «Актуальные вопросы адаптации человека» способствует выстраиванию партнерских от- 
ношений с вузами и научными организациями Югры, Тюмени, Ямала.

Основными целями научного семинара «Актуальные вопросы адаптации человека» является:

- анализ, обобщение и обмен знаниями и опытом в области научного знания об адаптации организма человека;

— апробация полученных результатов научной деятельности;

- координация научных исследований в рамках темы семинара.

Функциями научного семинара «Актуальные вопросы адаптации человека» являются:

- вовлечение в обсуждение актуальных научных проблем аспирантов, магистрантов, преподавателей вузов, научных сотрудников Ханты-Мансийского автономного округа - Югры, Тюменской области, Ямало-Ненецкого автономного округа, заинтересованных специалистов других территорий;

- развитие межвузовской научной кооперации;

- выявление интересных совместных исследовательских проектов для их дальнейшей реализации;

- апробация результатов научных исследований, развернутое обсуждение теоретических вопросов, связанных с адаптацией человека;

- экспертное сопровождение исследовательских проектов;

- стимулирование творческой активности и побуждение к решению научных проблем.

\section{Формы проведения семинара:}

- дискуссии по современным проблемам научного знания;

- тренинги;

- коллоквиумы по обсуждению материалов периодических отечественных и зарубежных научных изданий;

- презентации по результатам собственных исследований;

- мастер-классы и презентации, приглашенных к участию в семинаре сторонних исследователей;

- кейсы, деловые игры и дискуссии по актуальным проблемам соответствующей области науки;

- предварительная защита диссертаций магистрантов и аспирантов.

- представление результатов индивидуальных научных исследований;

- теоретические исследования, литературные обзоры;

- обсуждение теоретических проблем, основных положений монографий, учебных пособий, статей и т.д.;
- подготовка обзоров по новинкам специальной литературы и архивным материалам по профилю обучения;

- подготовка докладов и научных сообщений для участия в теоретических и научно-практических конференциях;

- подготовка научных работ для участия в конкурсах научных работ обучающихся;

- обсуждение публикаций по результатам проведенных исследований.

Роль руководителя научного семинара состоит в организации и координации научной работы слушателей, а также формирования дискуссионного пространства.

Основные функции руководителя семинара:

- разработка содержательной и организационной части программы семинара; • организация и проведение научных и научно-практических круглых столов, и мини-конференций, мастер-классов;

- участие в организации и проведении конкурсов научных работ;

- проведение консультаций по проводимому научному исследованию.

Научный семинар - это форма работы в вузе, которая позволяет ведущим исследователям, аспирантам, студентам, магистрантам выстроить эффективную научную коммуникацию для проработки актуальных научных тем. Научный семинар может являться важным средством сплочения исследовательского коллектива, выработки у его членов общих подходов, воззрений. Обсуждение на кафедрах научно-исследовательских работ, проведение научных семинаров и научных дискуссий создают ту питательную среду, которая обеспечивает непрерывный научный рост профессорско-преподавательского состава. Научные семинары проводятся, как правило, в рамках одной научной организации или одного учебного заведения, хотя на их заседания могут приглашаться и представители других организаций [1, 4].

Семинар ориентирован на развитие у слушателей мотивации к включению в реальные исследовательские проекты. Научный семинар представляет собой площадку для развития ключевых навыков, которыми должны овладеть обучающиеся (студенты, магистранты, аспиранты) [1, 2].

Каждый слушатель участвует в работе научного семинара, представляя доклад, сообщение, презентацию, аннотацию монографию, анализ новых публикаций по направлению работы семинара. Характер исследовательской работы в рамках семинара может носить научно-исследовательский, научно-методический и, в ред- 
ких случаях, реферативный характер.

Научные семинары играют важную роль в подготовке молодых специалистов [4, 7]. Проведение семинаров способствует успешному использованию сложных теоретических проблем в учебном процессе, расширению научных связей, формированию навыков академического письма и создания, а также представления презентаций, развитию научно-исследовательской компетенции обучающихся, становлению у них совокупности знаний, умений, свойств и качеств личности, необходимых для выполнения научной деятельности, а так же способствует формированию психологической готовности к публичному выступлению, воспитывает культуру ведения научной дискуссии, оказывает научно-методическую поддержку молодым ученым.

\section{Зак^ючение}

Таким образом, научный семинар «Актуальные вопросы адаптации человека» является эффективной формой научной коммуникации. Семинар позволяет сделать научную работу аспирантов и магистрантов постоянным и систематическим элементом образовательного процесса, включить обучающихся в среду научного сообщества кафедры и университета, реализовать потребности начинающих исследователей в знакомстве с широким кругом научно-исследовательских проблем, формировании актуального стиля научно-исследовательской деятельности на основе изучения опыта ученых, ознакомлении с методами и формами научно-исследовательской работы, вовлечь состоявшихся ученых и специалистов в экспертную деятельность.

\section{ЛИТЕРАТУРА}

1. Андрощук В.А. Современный семинар в высшей школе и его особенности // Альманах современной науки и образования. - 2009. - №10-2. - С. 17-18.

2. Косенок С.М., Литовченко 0.Г. Стратегическое развитие севера России - приоритет научной и инновационной деятельности высшей школы Югры // Сб «Север и Артика в новой парадигме мирового развития». Лузинские чтения, Магадан, 2016. - С. 459-466.

3. Лаврушин 0.И., Соколинская Н.Э. 0 научной работе и о научно-исследовательских семинарах в высшей школе // Экономика. Бизнес. Банки, 2020. №1(39). - с. 64-85.

4. Миронова М.Н. Научно-методический семинар как форма организации научно-исследовательской работы магистрантов и формирования профессиональных компетенций // Alma mater (Вестник высшей школы), 2014. - №2. - С. 63-67.

5. Розанова Н.М. Трансформация высшего образования: ключевые закономерности и долгосрочные тенденции // Вестник Института экономики Российской академии наук. 2020. - № 5. С. 64-78.

6. Фирстов В.Г. Роль и функции научных семинаров в развитии инновационной деятельности университетов // Инновации и инвестиции. 2019. № 4. С.2730.

7. Шибкова Д.З. Роль «научного семинара» в подготовке магистров к научно-исследовательской деятельности по эколого-биологическому образованию // Экология в средней и высшей школе: синтез науки и образования. Челябинск, 18-19 февраля, 2016. - С. 171-175.

(с) Литовченко Ольга Геннадьевна (olgalitovchenko@mail.ru). 